\title{
Cashin and Graf: long-term intraperitoneal 5-fluorouracil is superior to adjuvant FOLFOX in a randomized trial
}

\author{
Paul H. Sugarbaker ${ }^{1}$, Kurt Van der Speeten ${ }^{2}$ \\ ${ }^{1}$ MedStar Washington Hospital Center, Washington, DC, USA; ${ }^{2}$ Department of Surgery, Hospital Oost-Limburg, Genk, Belgium \\ Correspondence to: Paul H. Sugarbaker, MD. MedStar Washington Hospital Center, Washington, DC, USA. Email: Paul.Sugarbaker@outlook.com; \\ Kurt Van der Speeten. Department of Surgery, Hospital Oost-Limburg, Genk, Belgium. Email: Kurt.Vanderspeeten@zol.be. \\ Comment on: Cashin PH, Graf W. Sequential postoperative intraperitoneal chemotherapy for colorectal cancer with peritoneal metastases: a narrative \\ review. J Gastrointest Oncol 2021;12:S131-5.
}

Submitted Dec 16, 2020. Accepted for publication Mar 16, 2021.

doi: 10.21037/jgo-2020-16

View this article at: http://dx.doi.org/10.21037/jgo-2020-16

In this contribution by Cashin and Graf, the benefits of sequential postoperative intraperitoneal chemotherapy (SPIC) with single agent 5 -fluorouracil are presented (1). In this context, it is important to understand that after 50 years of their use; fluoropyrimidines are still the cornerstone of any successful chemotherapy regimen in colorectal cancer. SPIC is a combination of EPIC and NIPEC continued for 6 months postoperatively. When SPIC is compared to modern systemic chemotherapy, the overall survival was 25 vs. 18 months $(\mathrm{P}=0.04)$. These authors suggest that the first next step is to investigate a combination of HIPEC plus SPIC.

\section{Acknowledgments}

Funding: None.

\section{Footnote}

Provenance and Peer Review: This article was commissioned by the editorial office, Fournal of Gastrointestinal Oncology for the focused issue "Intraperitoneal Chemotherapy for Peritoneal Metastases: HIPEC, EPIC, NIPEC, PIPAC and More". The article did not undergo external peer review.

Conflicts of Interest: Both authors have completed the ICMJE uniform disclosure form (available at http:// dx.doi.org/10.21037/jgo-2020-16). The focused issue was sponsored by the Peritoneal Surface Oncology Group International (PSOGI). Drs. PHS and KVDS served as the unpaid Guest Editors of the focused issue. The authors have no other conflicts of interest to declare.

Ethical Statement: The authors are accountable for all aspects of the work in ensuring that questions related to the accuracy or integrity of any part of the work are appropriately investigated and resolved.

Open Access Statement: This is an Open Access article distributed in accordance with the Creative Commons Attribution-NonCommercial-NoDerivs 4.0 International License (CC BY-NC-ND 4.0), which permits the noncommercial replication and distribution of the article with the strict proviso that no changes or edits are made and the original work is properly cited (including links to both the formal publication through the relevant DOI and the license). See: https://creativecommons.org/licenses/by-nc-nd/4.0/.

\section{References}

1. Cashin PH, Graf W. Sequential postoperative intraperitoneal chemotherapy for colorectal cancer with peritoneal metastases: a narrative review. J Gastrointest Oncol 2021;12:S131-5.

Cite this article as: Sugarbaker PH, Van der Speeten K. Cashin and Graf: long-term intraperitoneal 5-fluorouracil is superior to adjuvant FOLFOX in a randomized trial. J Gastrointest Oncol 2021;12(Suppl 1):S136. doi: 10.21037/jgo2020-16 